\title{
MATHEMATICAL MODEL OF GAS HYDRATE OF HYDROGEN SULFIDE FORMATION DURING ITS INJECTION INTO A NATURAL LAYER
}

\author{
M.K. Khasanov ${ }^{1}$, G.R. Rafikova ${ }^{2}$ \\ ${ }^{1}$ Sterlitamak branch of Bashkir State University, Sterlitamak, Russian Federation, \\ ${ }^{2}$ Mavlyutov Institute of Mechanics UFRC RAS, Ufa, Russian Federation \\ E-mail: hasanovmk@mail.ru, rafikova_guzal@mail.ru
}

\begin{abstract}
The mathematical model of liquid hydrogen sulfide injection into the semi-infinite porous layer saturated with the oil and water accompanied by $\mathrm{H}_{2} \mathrm{~S}$ gas hydrate formation is presented here. We considered the case when the hydrate formation occurs at the frontal border and the oil displacement's front by hydrogen sulfide is ahead of this boundary. Solutions for pressure and temperature in every layer's area are built by help of the selfsimilar variable formation method. The values of the parameters of the moving interphase boundaries are found as the result of the iteration procedure. The coordinate dependence of phase boundaries on the injection pressure was studied on the basis of the obtained solutions. We have established that for the existence of solution with two different interphase boundaries, the injection pressure must be above a certain limiting value. The dependence of the limiting value of pressure on the initial temperature of the layer at different temperatures of the injected hydrogen sulphide is constructed. The results of the calculations showed that the constructed mathematical model with three areas in the reservoir gives an adequate description of the process at high injection pressures, the temperature of the injected hydrogen sulfide and the initial temperature of the layer.
\end{abstract}

Keywords: mathematical model; self-similar variable solution; porous medium; filtration; gas hydrates; hydrogen sulfide.

\section{Introduction}

One of the methods for the emission's reducing of hydrogen sulfide generated by industrial facilities into the atmosphere is its underground disposal in the exhausted hydrocarbon deposits $[1,2]$. As there is a risk of the leaking of the recyclable gases in the form of a fluid to the surface at their long-term underground storage we consider the possibility of their transformation into the gas hydrate state which allows the storing of the same gas number at much lower pressures compared to its free state $[3,4]$.

As any technological ideas need to be backed up by the relevant calculations based on the theoretical models, the construction of the adequate mathematical models of hydrate formation in the natural layers is an actual task. The mathematical models of hydrate formation in the porous layers saturated with methane and water are represented in the works [5-8]. The mathematical model of $\mathrm{H}_{2} \mathrm{~S}$ hydrate formation in the layers saturated with oil and water during injection of fluid hydrogen sulfide are represented in the work [9]. But in the above mentioned works the task is achieved due to its simple determination when the gas hydrate formation occurs at the border coinciding with the oil replacement's border by hydrogen sulfide. The mathematical model of $\mathrm{H}_{2} \mathrm{~S}$ gas hydrate formation is represented in this work the hydrate formation at the front border that doesn't coincide with the oil replacement's border by the fluid hydrogen sulfide. 


\section{Problem Statement}

The conditions of gas hydrate of hydrogen sulfide existence are represented in the phase diagram (Fig. 1) [6]. The curve line $g h$ determines in this diagram the three-phase balancing of water, gas hydrogen sulfide and its gas hydrate, the curve line $l h$ shows the balancing of water, fluid hydrogen sulfide and its gas hydrate, the curve line $l g$ represents two-phase balancing of fluid and gas hydrogen sulfide. Suitably the gas hydrate of hydrogen sulfide is to the left of the curve lines $g h$ and $l h$. All four indicated phases are balanced in the quadrupole point $\mathrm{Q}\left(T_{Q}=302,6 \mathrm{~K}\right.$ and $\left.p_{Q}=2,24 \mathrm{MPa}\right)$.

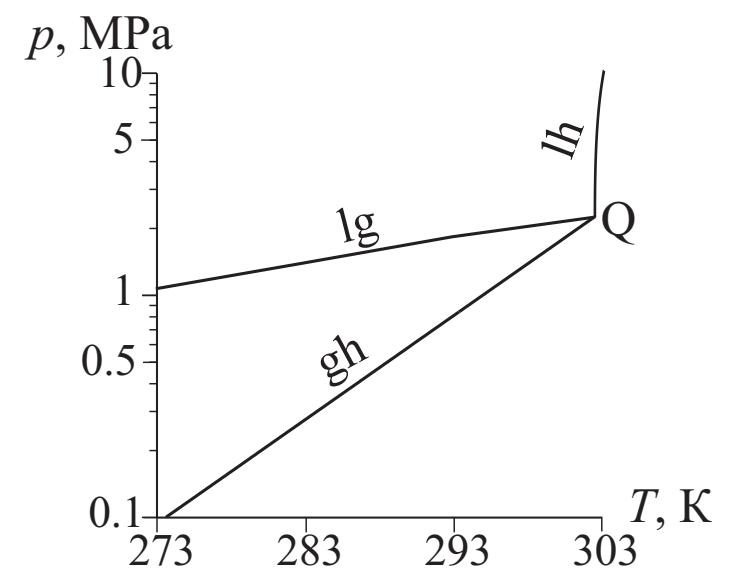

Fig. 1. Phase diagram of $\mathrm{H}_{2} \mathrm{~S}-\mathrm{H}_{2} 0$ system

Imagine the semi-finite horizontal porous layer (occupied semi-areas $x>0$ ) is saturated with water source saturation $S_{w 0}$ and oil in the initial moment. We assume that the initial temperature of the layer $T_{0}$ is higher than the temperature $T_{Q}$ of the accordance quadrupole point. Therefore the problem in question the initial position of the layer doesn't meet the formation conditions of the gas hydrate of hydrogen sulfide. Suppose that the fluid hydrogen sulfide is pumped through the border $(x=0)$ and the pe pressure as well as the $T_{e}$ temperature are in accordance with the conditions of the gas hydrate of hydrogen sulfide.

The initial and border conditions are $S_{w}=S_{w 0}, T=T_{0}, p=p_{0}(x \geq 0)$ when $t=0$, and the border conditions are $T=T_{e}, p=p_{e}(t>0)$ when $x=0$.

We consider the model with the oil piston displacement by hydrogen sulfide as well as the case when the value of the initial water saturation of the layer isn't higher than 0,2 (i.e. the water is immobile) in the work. Also we consider the time scales that are much higher than the characteristic time of the process of hydrate formation kinetics. So we can suppose that hydrate formation occurs at the front border which doesn't coincide with the oil displacement border by the hydrogen sulfide. Therefore three characteristic areas appear in the layer in accordance with this case. The pores are saturated with hydrogen sulfide and its hydrate in the first (nearest) area, the water and the hydrogen sulfide are in the second (intermediate) area, the pores saturated with oil and water are in the third (remote) one. Accordingly, there are two movable interfacial surfaces: between the first and the second areas where the water transforms into the gas hydrate state completely (front hydrate formation) and between the second and the third areas where the oil displacement by hydrogen sulfide occurs (displacement front). 


\section{Basic Equations}

Let's assume the following simplifying assumptions: the porosity of the layer $m$ is constant, the body of the porous medium, gas hydrate as well as the water are incompressible and immobile. $\mathrm{H}_{2} \mathrm{~S}$ gas hydrate is a double-component system with $G$ mass concentration of the hydrogen sulfide. We assume that the fluid hydrogen sulfide and the oil are weakly compressible fluids. Basic equation system describing in the one-dimensional case the filtration and heat transfer process in the porous medium represents the laws of mass energy conservation, Darcy law and equation of state [10]:

$$
\left\{\begin{array}{l}
\frac{\partial}{\partial t}\left(\rho_{i} m S_{i}\right)+\frac{\partial}{\partial x}\left(\rho_{i} m S_{i} v_{i}\right)=0 \\
\rho c \frac{\partial T}{\partial t}+\rho_{i} c_{i} m S_{i} v_{i} \frac{\partial T}{\partial x}=\frac{\partial}{\partial x}\left(\lambda \frac{\partial T}{\partial x}\right) \\
m S_{i} v_{i}=-\frac{k_{i}}{\mu_{i}} \frac{\partial p}{\partial x} \\
\rho_{i}=\rho_{0 i}\left(1+\beta_{i}\left(p-p_{0}\right)\right) .
\end{array}\right.
$$

Where $t$ is time; $x$ is coordinate; $m$ is porosity; $p$ is pressure; $T$-is temperature; low indexes $i=s, l$ refer respectively to the parameters of hydrogen sulfide and oil; $\rho_{i}$ is density; $k_{i}$ is phase permeability; $v_{i}$ is actual average speed; $c_{i}$ is specific heat capacity; $\mu_{i}$ is dynamic viscosity; $\beta_{i}$ is compressibility factor; $\rho c$ и $\lambda$ are effective values of the volumetric heat capacity and thermal conductivity of the layer saturated. Since the main contribution to the value $\rho \mathrm{c}$ and $\lambda$ includes the corresponding parameters of the rock we assume them as the constant values.

The phase coefficient dependence of the $k_{i}$ permeability on the $S_{(i)}$ saturation and absolute permeability $k_{0}$ we define as follows: $k_{i}=k_{0} S_{i}(i=s, l)$.

The total transition of the water into the hydrate state takes place on the surface $x=x_{(n)}$ dividing the first and the second areas. Therefore, according to the conditions of the mass heat balance at this boundary we have:

$$
\begin{gathered}
-\frac{k_{s(1)}}{\mu_{s}} \frac{\partial p_{(1)}}{\partial x}+\frac{k_{s(2)}}{\mu_{s}} \frac{\partial p_{(2)}}{\partial x}=m S_{h}\left(\frac{\rho_{h} G}{\rho_{0 s}}+\frac{\rho_{h}(1-G)}{\rho_{w}}-1\right) \dot{x}_{(n)}, \\
m S_{h} \rho_{h}(1-G) \dot{x}_{(n)}=m S_{w 0} \rho_{w} \dot{x}_{(n)}, \\
\lambda \frac{\partial T_{(1)}}{\partial x}-\lambda \frac{\partial T_{(2)}}{\partial x}=m S_{h} \rho_{h} L_{h} \dot{x}_{(n)},
\end{gathered}
$$

where the value $x_{(n)}$ is the front motion speed of the gas hydrate formation $\mathrm{H}_{2} \mathrm{~S}, G$ is mass concentration of the hydrogen sulfide in the hydrate, $L_{h}$ is specific heat of $\mathrm{H}_{2} \mathrm{~S}$ gas hydrate formation, $S_{w 0}$ is initial water saturation, $\rho_{w}$ is water density. Low index $n$ refers to the parameters at the border, dividing the first and the second areas, the low indexes 1 and 2 refer to the parameters of the first and the second areas accordingly. We assume the temperature at this border as continuous and equal to the temperature of the quadrupole point $T_{Q}$.

The oil displacement by the hydrogen sulfide takes place on the surface $x=x_{(d)}$ dividing the second and the third areas. Therefore we have the subject to the conditions of the oil and the hydrogen sulfide mass balance as well as the heat's one at this border:

$$
-\frac{k_{s(2)}}{\mu_{s}} \frac{\partial p_{(2)}}{\partial x}=m\left(1-S_{w 0}\right) \dot{x}_{(d)},
$$




$$
\begin{gathered}
-\frac{k_{l}}{\mu_{l}} \frac{\partial p_{(3)}}{\partial x}=m\left(1-S_{w 0}\right) \dot{x}_{(d)}, \\
\lambda \frac{\partial T_{(2)}}{\partial x}-\lambda \frac{\partial T_{(3)}}{\partial x}=0
\end{gathered}
$$

where the value $\dot{x}_{(d)}$ is the front motion speed of the oil by the hydrogen sulfide. Low index $d$ refers to the parameters at the border, dividing the second and the third areas and the low index 3 refers to the parameters of the third area.

The pressure and temperature will be considered continuous variables at both borders.

On the basis of the system's equations (1), the equations for the piezoconductivity and the temperature conductivity will be written in the form:

$$
\begin{gathered}
\frac{\partial p_{(i)}}{\partial t}=\chi_{(i)}^{(p)} \frac{\partial}{\partial x}\left(\frac{\partial p_{(i)}}{\partial x}\right) \\
\frac{\partial T_{(i)}}{\partial t}=\chi^{(T)} \frac{\partial}{\partial x}\left(\frac{\partial T_{(i)}}{\partial x}\right)+\frac{1}{2} \chi^{(T)} \mathrm{X}_{(i)} \frac{\partial p_{(i)}}{\partial x} \frac{\partial T}{\partial x}
\end{gathered}
$$

where $\chi_{(1)}^{(p)}=\frac{k_{s(1)}}{\mu_{s} m\left(1-S_{h}\right) \beta_{s}}, \quad \chi_{(2)}^{(p)}=\frac{k_{s(2)}}{\mu_{s} m\left(1-S_{w 0}\right) \beta_{s}}, \quad \chi_{(3)}^{(p)}=\frac{k_{l}}{\mu_{l} m\left(1-S_{w 0}\right) \beta_{l}}$, $\chi^{(T)}=\frac{\lambda}{\rho c}, \mathrm{X}_{(1)}=2 \frac{\rho_{0 s} c_{s} k_{s(1)}}{\lambda \mu_{s} \beta_{s}}, \mathrm{X}_{(2)}=2 \frac{\rho_{0 s} c_{s} k_{s(2)}}{\lambda \mu_{s} \beta_{s}}, \mathrm{X}_{(3)}=2 \frac{\rho_{0 l} c_{l} k_{l}}{\lambda \mu_{l} \beta_{l}}$.

\section{Self-Similar Solution}

We introduce self-similar variable: $\xi=x / \sqrt{\chi^{(T)} t}$. For this variable the equations (8), (9) for the piezoconductivity and temperature conductivity will take the form in every area:

$$
\begin{gathered}
-\xi \frac{d p_{(i)}}{d \xi}=2 \eta_{(i)} \frac{d}{d \xi}\left(\frac{d p_{(i)}}{d \xi}\right) \\
-\xi \frac{d T_{(i)}}{d \xi}=X_{(i)} \frac{d p_{(i)}}{d \xi} \frac{d T_{(i)}}{d \xi}+2 \frac{d}{d \xi}\left(\frac{d T_{(i)}}{d \xi}\right),
\end{gathered}
$$

where $\eta_{(i)}=\chi_{(i)}^{(p)} / \chi^{(T)}$.

After integrating the solutions (10), (11) the solutions for the pressure and temperature distribution in every area can be written in the form:

$$
\begin{gathered}
p_{(1)}=p_{(\mathrm{n})}+\frac{\left(p_{\mathrm{e}}-p_{(\mathrm{n})}\right) \int_{\xi}^{\xi_{(n)}} \exp \left(-\frac{\xi^{2}}{4 \eta_{(1)}}\right) d \xi}{\int_{0}^{\xi_{(n)}} \exp \left(-\frac{\xi^{2}}{4 \eta_{(1)}}\right) d \xi}, \\
T_{(1)}=T_{(n)}+\frac{\left(T_{e}-T_{(n)}\right) \int_{\xi}^{\xi_{(n)}} \exp \left(-\frac{\xi^{2}}{4}-X_{(1)} p_{(1)}\right) d \xi}{\int_{0}^{\xi_{(n)}} \exp \left(-\frac{\xi^{2}}{4}-X_{(1)} p_{(1)}\right) d \xi},
\end{gathered}
$$




$$
\begin{gathered}
p_{(2)}=p_{(\mathrm{d})}+\frac{\left(p_{(\mathrm{n})}-p_{(\mathrm{d})}\right) \int_{\xi}^{\xi_{(d)}} \exp \left(-\frac{\xi^{2}}{4 \eta_{(2)}}\right) d \xi}{\int_{\xi_{((n)}}^{\xi_{(d)}} \exp \left(-\frac{\xi^{2}}{4 \eta_{(2)}}\right) d \xi}, \\
T_{(2)}=T_{(d)}+\frac{\left(T_{(n)}-T_{(d)}\right) \int_{\xi}^{\xi_{(d)}} \exp \left(-\frac{\xi^{2}}{4}-X_{(2)} p_{(2)}\right) d \xi}{\int_{\xi_{(n)}}^{\xi_{(d)}} \exp \left(-\frac{\xi^{2}}{4}-X_{(2)} p_{(2)}\right) d \xi} \\
p_{(3)}=p_{0}+\frac{\left(p_{(\mathrm{d})}-p_{0}\right) \int_{\xi}^{\infty} \exp \left(-\frac{\xi^{2}}{4 \eta_{(3)}}\right) d \xi}{\int_{\xi_{(d)}}^{\infty} \exp \left(-\frac{\xi^{2}}{4 \eta_{(3)}}\right) d \xi}, \\
T_{(3)}=T_{0}+\frac{\left(T_{(d)}-T_{0}\right) \int_{\xi}^{\infty} \exp \left(-\frac{\xi^{2}}{4}-X_{(3)} p_{(3)}\right) d \xi}{\int_{(d)}^{\infty} \exp \left(-\frac{\xi^{2}}{4}-X_{(3)} p_{(3)}\right) d \xi}
\end{gathered}
$$

On the basis of the ratios (2), (4) taking into account the decisions (12), (13) we get the equations for coordinate's determining for the hydrate formation's front $\xi_{(n)}$ and parameter values on it:

$$
\begin{gathered}
k_{s(2)} \frac{\left(p_{(d)}-p_{(n)}\right) \exp \left(-\frac{\xi_{(n)}^{2}}{4 \eta_{(2)}}\right)}{\int_{\xi_{(n)}}^{\xi_{(d)}} \exp \left(-\frac{\xi^{2}}{4 \eta_{(2)}}\right) d \xi}-k_{s(1)} \frac{\left(p_{(n)}-p_{e}\right) \exp \left(-\frac{\xi_{(n)}^{2}}{4 \eta_{(1)}}\right)}{\int_{0}^{\xi_{(n)}} \exp \left(-\frac{\xi^{2}}{4 \eta_{(1)}}\right) d \xi}=K S_{h} \xi_{(n)}, \\
\frac{\left(T_{(n)}-T_{e}\right) \exp \left(-\frac{\xi_{(n)}^{2}}{4}-X_{(1)} p_{(n)}\right)}{\int_{0}^{\xi_{(n)}} \exp \left(-\frac{\xi^{2}}{4}-X_{(1)} p_{(1)}\right) d \xi}-\frac{\left(T_{(d)}-T_{(n)}\right) \exp \left(-\frac{\xi_{(n)}^{2}}{4}-X_{(2)} p_{(n)}\right)}{\int_{(d)} \exp \left(-\frac{\xi^{2}}{4}-X_{(2)} p_{(2)}\right) d \xi}= \\
=\frac{m \rho_{h} L_{h}}{2 \rho c} S_{h} \xi_{(n)}, \\
T_{(n)}=T_{Q},
\end{gathered}
$$

where $K=m \mu_{s} \chi^{(T)}\left(\frac{\rho_{h} G}{\rho_{s 0}}+\frac{\rho_{h}(1-G)}{\rho_{w}}-1\right)$.

Similarly, on the basis of the ratios (5) to (7) taking into account the decisions (13) and (14) we get the equations system to determine the oil displacement front's coordinate by hydrogen sulfide $\xi_{(d)}$ and parameter values on it:

$$
k_{s(2)} \frac{\left(p_{(n)}-p_{(d)}\right) \exp \left(-\frac{\xi_{(d)}^{2}}{4 \eta_{(2)}}\right)}{\int_{\xi_{(n)}}^{\xi_{(d)}} \exp \left(-\frac{\xi^{2}}{4 \eta_{(2)}}\right) d \xi}=m \mu_{s} \chi^{(T)}\left(1-S_{w 0}\right) \xi_{(d)},
$$




$$
\begin{gathered}
k_{l} \frac{\left(p_{(d)}-p_{0}\right) \exp \left(-\frac{\xi_{(d)}^{2}}{4 \eta_{(3)}}\right)}{\int_{\xi_{(d)}}^{\infty} \exp \left(-\frac{\xi^{2}}{4 \eta_{(3)}}\right) d \xi}=m \mu_{l} \chi^{(T)}\left(1-S_{w 0}\right) \xi_{(d)}, \\
\frac{\left(T_{(d)}-T_{(n)}\right) \exp \left(-\frac{\xi_{(d)}^{2}}{4}-\mathrm{X}_{(2)} p_{(d)}\right)}{\int_{\xi_{(n)}}^{\xi_{(d)}} \exp \left(-\frac{\xi^{2}}{4}-X_{(2)} p_{(2)}\right) d \xi}-\frac{\left(T_{0}-T_{(d)}\right) \exp \left(-\frac{\xi_{(d)}^{2}}{4}-\mathrm{X}_{(3)} p_{(d)}\right)}{\int_{\xi_{(d)}}^{\infty} \exp \left(-\frac{\xi^{2}}{4}-X_{(3)} p_{(3)}\right) d \xi}=0 .
\end{gathered}
$$

The system of boundary equations (15) to (20) is presented in the work as following. At the beginning the zero approximation of the desired values at the front of hydrate formation is given. Further, solving the equation (18), we find the $p_{(d)}$ value (as a function $\left.\xi_{(d)}\right)$, substituting that into equation (19) we get the transcendental equation for finding $\xi_{(d)}$. Have solved this equation (by the half division method) we determine the value $\xi_{(d)}$ (and respectively $\left.p_{(d)}\right)$, then from (20) we define $T_{(d)}$. Further, substituting (17) into the equation (16) we get the transcendental equation for finding $\xi_{(n)}$. Solving this equation (by the method of half-division), we determine new approximation of value $\xi_{(n)}$. Then, solving equation (15), we find a new approximation of value $p_{(n)}$. As the result of cyclic repetition of the described iterative procedure we obtain a sequence of approximate values which converges to the target values of the boundary parameters. As a result of cyclic repetition of the described iterative procedure, we obtain a sequence of approximate values $Y_{(k)}=\left(\xi_{(n)}, \xi_{(d)}, p_{(n)}, p_{(d)}, T_{(d)}\right)$. This sequence converges within the metric:

$$
\begin{gathered}
\rho\left(Y^{(k+1)}, Y^{(k)}\right)=\max \left(\left|\xi_{(n)}^{(k+1)}-\xi_{(n)}^{(k)}\right|,\left|\xi_{(d)}^{(k+1)}-\xi_{(d)}^{(k)}\right|,\right. \\
\left.\left|\frac{p_{(n)}^{(k+1)}}{p_{0}}-\frac{p_{(n)}^{(k)}}{p_{0}}\right|,\left|\frac{p_{(d)}^{(k+1)}}{p_{0}}-\frac{p_{(d)}^{(k)}}{p_{0}}\right|,\left|\frac{T_{(d)}^{(k+1)}}{T_{0}}-\frac{T_{(d)}^{(k)}}{T_{0}}\right|\right) .
\end{gathered}
$$

To establish the time of the termination of the iterations, the following condition was used:

$$
\rho\left(Y^{(k+1)}, Y^{(k)}\right)<0,001
$$

\section{Result of Calculation}

The Fig. 2 shows the dependence of the coordinate fronts of the hydrate formation $\mathrm{H}_{2} \mathrm{~S}$ (curve line1) and the oil displacement by the liquid hydrogen sulfide (curve line2) on the injection pressure. Hereinafter, unless otherwise specified for the parameters characterizing the system, the following values are adopted: $m=0,1, S_{w 0}=0,2, p_{0}=8 \mathrm{MPa}$, $T_{e}=290 \mathrm{~K}, T_{0}=305 \mathrm{~K}, k_{0}=10^{-11} \mathrm{~m}^{2}, G=0,24, \beta_{s}=3 \cdot 10^{-9} \mathrm{~Pa}^{-1}, \beta_{l}=1 \cdot 10^{-9} \mathrm{~Pa}^{-1}$, $\lambda=2 \mathrm{w} /(\mathrm{M} \cdot \mathrm{K}), \rho \mathrm{c}=2 \cdot 10^{6} \mathrm{~J} /(\mathrm{K} \cdot \mathrm{kg}), \mu_{s}=2 \cdot 10^{-4} \mathrm{~Pa} \cdot \mathrm{s}, \mu_{l}=2 \cdot 10^{-3} \mathrm{~Pa} \cdot \mathrm{s}, \rho_{h}=1003 \mathrm{~kg} / \mathrm{m}^{3}$, $\rho_{w}=1000 \mathrm{~kg} / \mathrm{m}^{3}, \rho_{0 s}=890 \mathrm{~kg} / \mathrm{m}^{3}, \rho_{0 l}=900 \mathrm{~kg} / \mathrm{m}^{3}, c_{s}=1800 \mathrm{~J} /(\mathrm{K} \cdot \mathrm{kg}), c_{l}=1900 \mathrm{~J} /(\mathrm{K} \cdot \mathrm{kg})$, $L_{h}=4,1 \cdot 10^{5} \mathrm{~J} / \mathrm{kg}$.

According to the Fig. 2 the speed of the first front is almost independent on the injection pressure and the speed of the second front increases with its growth. This is due to the fact that the front speed of the oil displacement by hydrogen sulfide is limited by 


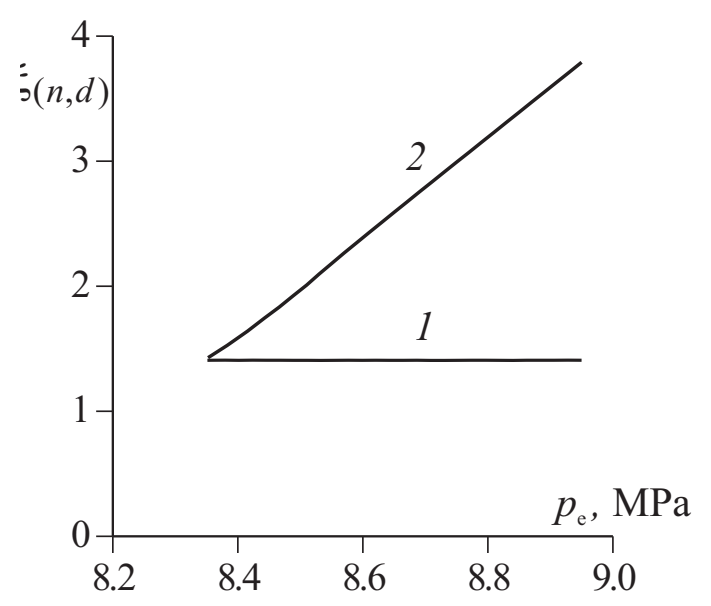

Fig. 2. Dependence of the border coordinates of hydrate formation $\mathrm{H}_{2} \mathrm{~S}$ (curve line 1) and oil displacement by hydrogen sulfide (curve line 2 ) on the injection pressure

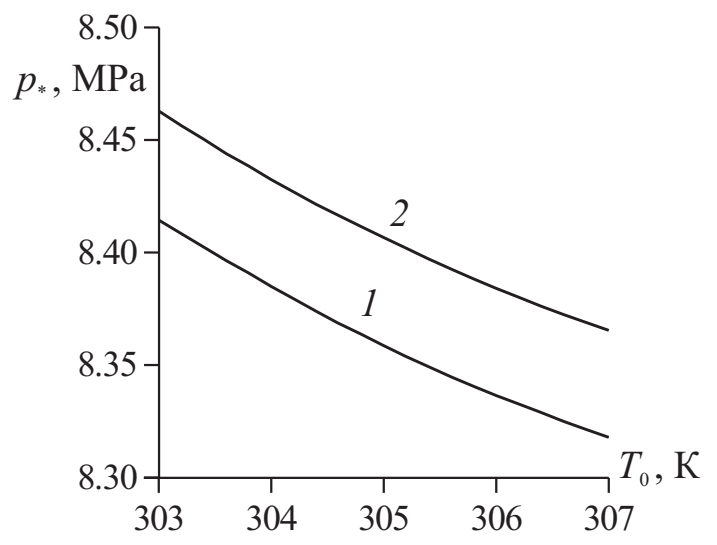

Fig. 3. The dependence of the limiting pressure on the initial temperature in the layer at $T_{e}=290 \mathrm{~K}$ (curve line 1 ) and $285 \mathrm{~K}$ (curve line 2)

the intensity of mass transfer in the layer that is proportional to the generated in the layer pressure drop according to Darcy's law. And the front speed of the hydrate formation is limited primarily by the dissipation of heat released during the phase transition, i.e. the intensity of heat transfer in the layer.

It is also seen that for the sufficiently low values of injection pressure the coordinates of both fronts are aligned, i.e. the front speed of the oil displacement by the liquid hydrogen sulfide is reduced to the speed of the hydrate formation front. Because the original hydrogen sulfide in the layer was absent, that in this mode, the speed of movement of united fronts will be limited by the supply of hydrogen sulfide, i.e. by the injection pressure.

Thus, there is some value of pressure (called limiting pressure) above which the mode with two different interfacial borders is implemented under consideration in this work. There are given in the Fig. 3 the dependences of the injection pressure corresponding to the alignment of the coordinates of both fronts, on the initial layer temperature at different injection temperatures $T_{e}=290 \mathrm{~K}$ (curve line 1 ) и $285 \mathrm{~K}$ (curve line 2 ). According to the Fig. 3 the given pressure value decreases while increasing the initial layer's temperature and temperature of hydrogen sulfide injected. In other words, the mode with two different interphase bounders is realized at sufficiently high layer's temperatures and the hydrogen sulfide injected. This is due to the fact that the intensity of heat removal at the border 
of hydrate formation decreases with an increase layer's temperature and the injection and, accordingly, the rate of hydrate formation front decreases. Thus, the front of oil displacement by hydrogen sulfide outpaces the front of $\mathrm{H}_{2} \mathrm{~S}$ gas hydrate formation even at low values of injection pressure at high temperatures of the layer and hydrogen sulfide injected.

Acknowledgements. This work was supported by the Russian Foundation for Basic Research and the Republic of Bashkortostan (project No. 17-48-020123).

\section{References}

1. Machel H.G. Geological and Hydrogeological Evaluation of the Nisku Q-Pool in Alberta, Canada, for $\mathrm{H}_{2} \mathrm{~S}$ and/or $\mathrm{CO}_{2}$ Storage. Oil and Gas Science and Technology, 2005, vol. 60, pp. 51-65. DOI: 10.2516/ogst:2005005

2. Xu T., Apps J.A., Pruess K., Yamamoto H. Numerical Modeling of Injection and Mineral Trapping of $\mathrm{CO}_{2}$ with $\mathrm{H}_{2} \mathrm{~S}$ and $\mathrm{SO}_{2}$ in a Sandstone Formation. Chemical Geology, 2007, vol. 24, no. 3-4, pp. 319-346. DOI: 10.1016/j.chemgeo.2007.03.022

3. Byk S.Sh., Makogon Yu.F., Fomina V.I. Gazovye gidraty [Gas Hydrates]. Moscow, Khimiya, 1980 .

4. Duchkov A.D., Sokolova L.S., Ayunov D.E., Permyakov M.E. Assesment of Potential of West Siberian Permafrost for the Carbon Dioxide Storage. Earth's Cryosphere, 2009, vol. 13, no 4, pp. $62-68$.

5. Gimaltdinov I.K., Khasanov M.K. Mathematical Model of the Formation of a Gas Hydrate on the Injection of Gas into a Stratum Partially Saturated with Ice. Journal of Applied Mathematics and Mechanics, 2016, vol. 80, no. 1, pp. 57-64. DOI: $10.1016 /$ j.jappmathmech.2016.05.009

6. Shagapov V.Sh., Rafikova G.R., Khasanov M.K. On the Theory of Formation of Gas Hydrate in Partially Water-Saturated Porous Medium when Injecting Methane. High Temperature, 2016, vol. 54, no. 6, pp. 858-866. DOI: 10.1134/S0018151X16060171

7. Shagapov V.Sh., Chiglintseva A.S., Belova S.V. On the Theory of Formation of a Gas Hydrate in a Heat-Insulated Space Compacted with Methane. Journal of Engineering Physics and Thermophysics, 2017, vol. 90, no. 5, pp. 1147-1161. DOI: 10.1007/s10891-017-1669-8

8. Shagapov V.Sh., Chiglintceva A.S., Belova S.V. Mathematical Modelling of Injection Gas Hydrate Formation into the Massif of Snow Saturated the Same Gas. Proceedings of the Mavlyutov Institute of Mechanics, 2016. vol. 11, no. 2, p. 233-239. DOI: 10.21662 /uim2016.2.034

9. Khasanov M.K. Injection of Liquid Hydrogen Sulfide in a Layer Saturated with Oil and Water. Tyumen State University Herald. Physical and Mathematical Modeling. Oil, Gas, Energy, 2017, vol. 3, no. 2, pp. 72-84.

10. Shagapov V.Sh., Khasanov M.K., Musakaev N.G., Ngoc Hai Duong. Theoretical Research of the Gas Hydrate Deposits Development Using the Injection of Carbon Dioxide. International Journal of Heat and Mass Transfer, 2017, vol. 107, pp. 347-357. DOI: $10.1016 /$ j.ijheatmasstransfer.2016.11.034

Received February 20, 2018 


\title{
МАТЕМАТИЧЕСКАЯ МОДЕЛЬ ОБРАЗОВАНИЯ ГАЗОГИДРАТА СЕРОВОДОРОДА ПРИ ЕГО ИНЖЕКЦИИ В ПРИРОДНЫЙ ПЛАСТ
}

\author{
М.К. Хасанов ${ }^{1}$, Г.Р. Рафикова \\ ${ }^{1}$ Стерлитамакский филиал Башкирского государственного университета, \\ г. Стерлитамак, Российская Федерация \\ ${ }^{2}$ Институт механики им. Р.Р. Мавлютова - обособленное структурное \\ подразделение Уфимского федерального исследовательского центра \\ Российской академии наук, г. Уфа, Российская Федерация
}

\begin{abstract}
Представлена математическая модель инжекции жидкого сероводорода в полубесконечный пористый пласт, насыщенный нефтью и водой, сопровождающейся образованием газогидрата $\mathrm{H}_{2} \mathrm{~S}$. Рассмотрен случай, когда гидратообразование происходит на фронтальной границе, а фронт вытеснения нефти сероводородом опережает данную границу. Методом сведения к автомодельной переменной построены решения для давления и температуры в каждой из областей пласта. Значения параметров подвижных межфазных границ найдены как результат итерационной процедуры. На основе полученных решений исследована зависимость координат межфазных границ от давления инжекции. Показано, что для существования решений с двумя различными межфазными границами величина давления инжекции должна быть выше некоторого предельного значения. Построена зависимость предельного значения давления инжекции от начальной температуры пласта при разных значениях температуры инжектируемого сероводорода. Результаты расчетов показали, что построенная математическая модель с тремя областями в пласте дает адекватное описание процесса при высоких значениях давления инжекции, температуры закачиваемого сероводорода и начальной температуры пласта.
\end{abstract}

Ключевые слова: математическал модель; автомодельное решение; пористая среда; фильтрация; газогидраты; сероводород.

Работа выполнена при финансовой поддержке РФФИ и Республики Башкортостан (проект № 17-48-020123 p_a).

\section{Литература}

1. Machel, H.G. Geological and Hydrogeological Evaluation of the Nisku Q-Pool in Alberta, Canada, for $\mathrm{H}_{2} \mathrm{~S}$ and/or $\mathrm{CO}_{2}$ Storage / H.G. Machel / Oil and Gas Science and Technology.2005. - V. 60. - P. 51-65.

2. $\mathrm{Xu}, \mathrm{T}$. Numerical Modeling of Injection and Mineral Trapping of $\mathrm{CO}_{2}$ with $\mathrm{H}_{2} \mathrm{~S}$ and $\mathrm{SO}_{2}$ in a Sandstone Formation / T. Xu, J.A. Apps, K. Pruess, H. Yamamoto // Chemical Geology. 2007. - V. 24, № 3-4. - P. 319-346.

3. Бык, С.Ш. Газовые гидраты / С.Ш. Бык, Ю.Ф. Макогон, В.И. Фомина. - М.: Химия, 1980 .

4. Дучков, А.Д. Оценка возможности захоронения углекислого газа в криолитозоне Западной Сибири / А.Д. Дучков, Л.С. Соколова, Д.Е. Аюнов, М.Е. Пермяков // Криосфера Земли. - 2009. - Т. 13, № 4. - С. 62-68.

5. Гималтдинов, И.К. Математическая модель образования газогидрата при инжекции газа в пласт, частично насыщенный льдом / И.К. Гималтдинов, М.К. Хасанов // Прикладная математика и механика. - 2016. - Т. 80, № 1. - С. 80-90. 
6. Шагапов, В.Ш. K теории образования газогидрата в частично водонасыщенной пористой среде при нагнетании метана / В.Ш. Шагапов, Г.Р. Рафикова, М.К. Хасанов // Теплофизика высоких температур. - 2016. - Т. 54, № 6. - С. 911-920.

7. Шагапов, В.Ш. К теории процесса образования газогидрата в замкнутом теплоизолированном объеме, опрессованном метаном / В.Ш. Шагапов, А.С. Чиглинцева, С.В. Белова // Инженерно-физический журнал. - 2017. - Т. 90, № 5. - С. 1208-1222.

8. Шагапов, В.Ш. Математическое моделирование нагнетания гидратообразующего газа в снежный массив, насыщенный тем же газом / В.Ш. Шагапов, А.С. Чиглинцева, С.В. Белова // Труды Института механики им. Р.Р. Мавлютова Уфимского научного центра PAH. - 2016. - T. 11, № 2. - C. 233-239.

9. Хасанов, M.K. Инжекция жидкого сероводорода в пласт, насыщенный нефтью и водой / M.K. Хасанов // Вестник Тюменского государственного университета. Физикоматематическое моделирование. Нефть, газ, энергетика. - 2017. - Т. 3, № 2. - С. 72-84.

10. Shagapov, V.Sh. Theoretical Research of the Gas Hydrate Deposits Development Using the Injection of Carbon Dioxide / V.Sh. Shagapov, M.K. Khasanov, N.G. Musakaev, Ngoc Hai Duong // International Journal of Heat and Mass Transfer. - 2017. - V. 107. - P. 347-357.

Марат Камилович Хасанов, кандидат физико-математических наук, доцент, кафедра «Прикладная информатика и программирование», Стерлитамакский филиал Башкирского государственного университета (г. Стерлитамак, Российская Федерация), hasanovmk@mail.ru.

Гузаль Ринатовна Рафикова, кандидат физико-математических наук, ученый секретарь, Институт механики им. Р.Р. Мавлютова - обособленное структурное подразделение Уфимского федерального исследовательского центра Российской академии наук (г. Уфа, Российская Федерация), rafikova_guzal@mail.ru.

Поступила в редакиию 20 февраля 2018 г. 